\title{
CONCEPT OF MEDIA LITERACY AND LIBRARY CAMPAIGNS
}

\author{
Dr. Priyanki Vyas \\ Ms. Kinjal G. Parmar
}

\begin{abstract}
Literacy become common word's among people, usually it defined the ability to read and write. Development of the information technology literacy develop in the form of various categories, i.e. Information literacy, media literacy, digital literacy etc. Media literacy is the ability to identify different types of media and understand the message they're sending. The library is place of sharing resources, ideas, information and knowledge with different media, because of the library also need require awareness of media literacy among users. Library have many kinds of media like social media, printed media, electronic media and digital media which help in creating media literacy among users. The digital era makes easy to create any kind of media. With the media literacy innovative ideas and activities should be introduce in form of library campaigns.
\end{abstract}

Keyword: Information Literacy, Media Literacy, Library Campaigns, Digital Literacy

\section{Introduction}

Society is place of emerging new culture, information, knowledge and wisdom which directly or indirectly impact on the social change, education, politics, and society. Literacy become common word's among people, usually it defined the ability to read and write. Development of the information technology literacy develop in the form of various categories, i.e. Information literacy, media literacy, digital literacy etc. Information spread as fire in the society with the use of media. It's become way to communicate message with people directly or indirectly. Media Literacy (ML) is a field and a movement that promotes and facilitates critical thinking skills oriented toward media messages. Media literacy is the ability to identify different types of media and understand the message they're sending. The message spread via different media should be positive or negative on users. Aim of media literacy is to create active, competent media users. 


\section{Definition}

"Media Literacy is the ability to access, analyze, evaluate and create media in a variety of forms."

Aspen Media Literacy Leadership Institute 1992

"Media literacy encompasses the practices that allow people to access, critically evaluate, and create or manipulate media."

\section{Review of Literature}

Nijboer, Jelke and Hammelburg (2009) conduct study on the extending media literacy: a new direction for library, where library as an expert center concerning literacy should respond, and anticipate playing a key role in improving media competency of schoolchildren, students and another citizen. This is new diversion for library where new and old generation both try to replace library with the mobile library. Trend include media production in the media literacy programmed is challenges for libraries.

Geek the Library: A Community Awareness Campaign, (OCLC Report) the research made clear that an effective library advocacy and marketing campaign in support of increased library funding must ensure that the library is repositioned as both a unique and essential part of the community infrastructure. It must attract attention and have stopping power. The library cannot be viewed as a place of information that's 'nice to have,' but as a 'must have' that's as important to the future as the past. An effective campaign must present today's library as a place of possibilities and as a critical asset-for individuals (to find jobs, reeducate themselves and enhance literacy) and for the community (access to technology, continued education and economic benefits).

Ubale Kabiru and Yahaya, Abdullahi (2016) study about the Library campaign as strategy for actualizing the sustainable Development goals in Nigeria: the role of librarian states the how library campaign use for the SDG. For development nation required relevant and update information about politics, social, democracy etc. The United nations SDGs recognized the interdependence between growth, poverty eradication and sustainable development so that achieved one of the expectations. 
Librarians should strive to acquired information material on sustainable development goals and aware library users.

\section{Objectives of research paper}

- To know the concept of media literacy and library campaign.

- To understand media literacy as tools for library campaign.

- To know the various media used in library for the media literacy for library campaign.

- To acknowledge library media to promote media literacy in library.

\section{Concept of Media Literacy in Library}

The library is place of sharing resources, ideas, information and knowledge with different media, because of the library also need require awareness of media literacy among users. Seven skill of media literacy is Analysis, Evaluation, Grouping, Induction, Deduction, Synthesis, Abstracting. With the tedious growth Library transfer from the traditional to digital. Implement library website for awareness of digital and electronic resources for that media literacy play vital role. Media literate people should be able to:

- Use media technology effectively to access, store, retrieved and share content

- User analyzed published media content

- Understand the whole picture of library collection and services

- Able to identify the correct information, and understand trustworthy services

- Gain access of resource for $24^{*} 7$

\section{Library campaign}

Libraries are thus established as the nation's single key arts resource - simply by doing what we all know they do. This needs to be properly acknowledged. This is not a power grab for the library sector. It is a concept that can offer a great many opportunities to the cultural sector in general. The library is place of sharing resources, ideas, information and knowledge with different media, because of the library also need require awareness of media literacy among users. Library have many kinds of media like social media, printed media, electronic media and digital media which help in creating media literacy among users. The digital era makes easy to create any kind of 
media. With the media literacy innovative ideas and activities should be introduce in form of library campaigns.

The Campaign for the World's Libraries is a public education campaign of the International Federation of Library Associations and Institutions, the American Library Association and libraries around the world to speak loudly and clearly about the value of libraries and librarians in the 21st century. It is designed to showcase the unique and vital roles played by public, school, academic and special libraries worldwide. (Campaign for the World's Libraries (@your Library) - IFLA)

Today librarian trays to comply new skill and survive them shelve with the emerging virtual information. Library campaign become vital and essential in the provision of library and information. Library campaign refers to series of action and activities embark upon by librarian to improve services delivery and better satisfaction of users.

\section{The core messages of the campaign}

- Libraries are changing and dynamic places

- Libraries are places of opportunity

- Libraries bridge the world

\section{Aim of Library campaign}

- to raise awareness about the variety of programs and services offered;

- to increase use of libraries at schools, at colleges and universities, in government, at work, and in daily community life;

- to increase funding for libraries;

- to involve librarians as stakeholders on public policy issues such as intellectual freedom, equity of access and the "digital divide;"

- To encourage librarianship as a profession.

\section{Different Strategies for Library Campaign}

Librarian play many roles in the library as resource person, information provider, network master, knowledge partner etc. The growth of library depends on many factors one of them is user who directly or indirectly use library, for their information needs. 
Every users or readers are not aware or use from every services and collection of libraries. To promote, market or campaign library and their resources librarian should try's different strategies

- Book Fair on different day's and events.

- Book Talk by expert on particular subject.

- Engaging target audience with interactive website.

- Arranges different professional games and role play using library collection e.g. Library card winner, Best reader, Library Sign up card etc.

- Through the library orientation, seminar and workshop.

\section{Media literacy as tools for library campaign}

The campaign's core message-everyone has something they are passionate about, something they geek and the library supports it all—resonated with a large percentage of the public in pilot communities. Library should encourage various library resource, services and knowledge using media literacy by targeting following sectors or fields.

- general public - parents, children, students, senior citizens and business people;

- educators, school groups and administrators;

- government leaders, policymakers and opinion leaders;

- librarians and those who are considering the library profession;

- media;

- Strategic partners, including funding agencies.

Media become tools for library campaign in staring point of library, to promote, encourage and improve level of satisfaction in library various events, program, orientation and literacy seminar should be arrange in form of library campaign. Media work as intermediate between the users and the library.

\section{Conclusion}

The era known as digital era, with the information literacy, media literacy new trend in digital era is digital literacy. In the development of library campaign digital literacy also play vital role with the media literacy. Library have new diversion in the digital literacy, it's virtual role of librarian behind the promotion of library, their resources, campaign and services through the media and digital tools. 


\section{References}

Daniel ciurel. "Media literacy: concepts, approaches and competencies". Professional communication and translation studies, 9, 2016

Jelke Nijboer and Esther Hammelbur. "Extending media literacy: a new direction for libraries". New Delhi world, 111(1/2), (2009).

Geek the Library: A Community Awareness Campaign, a Report to the OCLC Membership

https://www.ifla.org/about-the-campaign-for-the-worlds-libraries

https://www.ifla.org/at-your-library
Dr. Priyanki Vyas
Head/Associate Professor
Department of Library and Information Science
DR. Babasaheb Ambedkar Open University
$\&$
Kinjal G. Parmar
Assistant Professor
Department of Library and Information Science
DR. Babasaheb Ambedkar Open University 